\title{
Peacekeepers But Not Quite Peacebuilders: Japan's Evolving Role in the Middle East Peace Process
}

For an independent Japan, which is among the first rank of countries in economics, technology and learning to continue to be dependent on another country is a deformity (katawa) of the state ... For Japan, a member of the United Nations and expecting its benefits, to avoid support of its peacekeeping mechanisms is selfish behavior. This is unacceptable in international society. I myself cannot escape responsibility for the use of Constitution as a pretext (tatemae) for this way of conducting national policy.

Yoshida Shigeru in Sekai to Nippon, 1963

Since wars begin in the minds of men, it is in the minds of men that the defences of peace must be constructed.

UNESCO Charter

The author gratefully acknowledges the support of funding of this chapter by the Hong Kong Research Council General Research Fund, HKU Project number $753310 \mathrm{H}$.

(C) The Author(s) 2019

V. Teo, Japan's Arduous Rejuvenation as a Global Power, https://doi.org/10.1007/978-981-13-6190-6_4 


\section{Japan's Foray into the Middle East}

Japan's foray into the Middle East pre-dates the end of the Cold War. Even though Japan has largely kept a non-intervention posture as enshrined by its pacifist position throughout the Cold War, a critical indication of its normalization and rejuvenation is its ability to play a greater role in global affairs. There cannot be a better test for assessing the extent of Tokyo's normalization and rejuvenation drive than observing its behavior in the Middle East. This is particularly important as Japan has interests in the Middle East, putting Tokyo's position at odds with the official position that her principal ally, the United States, holds on the same issues, such as policy over Iran and military intervention in the Middle East. To that extent, the Middle East has become an area of critical importance to Tokyo.

Over the course of the last two decades, the dominant narrative on Japan's involvement in the Middle East has focused principally on the notion of "peacekeeping" (Suzuki 2013; Ishizuka 2005; Takahara 1996; Harrison and Nishihara 1995; Kozai 2001; Yamanaka 2003; Togo 2010: chapter 12; Dobson 2003; Leitenberg 1996). Most descriptions of Japan's "peace" activities focus on its dispatching of troops to support the US in Iraq; its deployment of minesweepers and refueling vessels to support the US in its War on Terror; and its participation in the anti-piracy efforts in the Gulf of Aden. All these activities are usually conducted under the auspices of the US-Japan alliance or under the UN mandate. Domestically, the narrative is framed within the twin objectives of supporting the alliance as well as fulfilling Japan's international obligations. Externally, the deployment of Japanese forces under the US or UN umbrella might make this more palatable for other Asian nations.

These activities complement a far more important and understated aspect of Japan's peacebuilding activities pursued through agencies such as the Japan International Cooperation Agency (JICA) and through Japan's foreign ministry since the institution of the Fukuda Doctrine in 1979. As part of Japan's global efforts, JICA has been very successful in integrating itself into the local activities of the regions it has targeted to help. Due to the JSDF's own constraints abroad, it has always participated in two categories of activities: disaster relief and domestic reconstruction. Japan has therefore always relied on this route to promote its soft power through humanitarian activities (Yoshizaki 2008: 107-120). ${ }^{1}$ Any narrative justified

\footnotetext{
${ }^{1}$ Tomonori Yoshizaki argues that even though the JSDF has been dispatched to Iraq, their deployment is still severely circumscribed as the Japanese contingent could only serve in "non-combat" zones, and more importantly refrained from participating in "stabilization"
} 
based on humanitarian grounds rather than premises of normalization or rejuvenation is always more palatable to the Japanese public.

After the collapse of the USSR, the Middle East has therefore taken on a new "instrumental" meaning for Tokyo. Deployment to the Middle East extends far beyond Japan's backyard of the Asia-Pacific. Such a move therefore severely tests Japan's constitutional limitations and both its long held, cherished notion of pacifism and its self-imposed restraints on Japan's defense forces. Such deployments will also increasingly socialize the Japanese people to Japan undertaking missions of global and regional significance.

Japan has been actively supporting the US in the region (Shelter-Jones 2012), but the extent of its involvement has been circumscribed due to domestic constraints, policy inertia and an understated deference to the US. In short, Japan's political stature and influence in regions outside of the Asia-Pacific cannot be regarded as commensurate with its credentials, financial contributions and resources devoted to developmental assistance.

A rejuvenated Japan must therefore first take into account its own interests and the sensitivities of others second, and must be able to partake actively in the region's important affairs, offering fresh ideas and perspectives on age-old problems. Despite the difficulties, Japan has made important strides in achieving this, particularly under Prime Minister Abe. Nonetheless, Japan's determination to increase its efforts is still carefully choreographed to ensure that there is some parity between increasing Japan's profile and preserving the unity of the US-Japan alliance.

Since the 1990s, Japan has decided to incrementally deviate from its traditional behavior in the region. Tokyo has decided to double down and extend support to US/UN operations in the region, ensuring the globalization of the US-Japan alliance. This directly assists Japan's aspirations to achieve rejuvenation as a global power on the back of a US global presence. Thus, over the last two decades, much of the focus of the Japanese polity has been centered on whether or not Japan should dispatch its military to the Middle East. Be it naval minesweepers and refueling tankers to support US missions in the Gulf, reconstruction brigades to Iraq, or naval ships to help fight piracy, the debate has always revolved around (i) the constitutionality of such deployments, (ii) the reasons for and against such missions, (iii) whether Japan should undertake such missions. The overall result is that the narrative involving Japan's activities in the Middle East revolves around Japan's incremental inroads in chipping away at the constraints of the constitution through such deployments. goodwill of other militaries to provide the force projection needed. 
This chapter argues, however, that when viewed from the perspective of Japan's rejuvenation, this focus on military deployment and peacekeeping is lopsided. If the neo-conservative's agenda is to transform Japan into a substantial power in all senses of the word, then Japan should also focus on its role as a peacebuilder rather than just within the frame of a peacekeeping role and a secondary combat support role. While not attempting to replace the role of the US in the peace process, Tokyo is attempting to mount complementary platforms that support Washington's efforts, particularly in an era where US foreign policy seems to have lost its balance. To that end, Japan has the requisite credentials to play a greater role than it has done in the past, given its historic status as a pacifist economic power, a US ally and a relatively neutral party in the Arab-Israeli dispute. This is not to suggest that Japan can replace any country in the peace process or even think from the get-go it can resolve the dispute all at once, but rather that Japan should aspire to have a greater political role in the region.

Japan has had a long history of undertaking work and activities that can be considered to be the core of peacebuilding activities. Between JICA, the foreign ministry and other related agencies, the Japanese government collectively dispatches billions of yen as loans, technical assistance and grassroots programs. This is done through the official overseas developmental assistance program and also bilateral programs administered by the foreign ministry. It would appear that JICA is far ahead of the Japanese foreign ministry when it comes to work done to help Japan reach out to places traditionally neglected by Japanese foreign policy.

The section below provides a brief overview of the Arab-Israeli conflict, and a discussion of Japan's evolving role. It then takes a step back and discusses these developments against the notions of normalization and rejuvenation.

\section{A Brief Synopsis of the Arab-Israeli Conflict}

The genesis of the problem began toward the end of the seventeenth century with the migration of Jewish people into the Ottoman Empire territory of Palestine, which had a sizable Muslim population. The impetus behind the migration was the significant historical and religious value of the sites located in Jerusalem for both Islam and Judaism. The Dome of the Rock (otherwise known as the Rock of Abraham) and the Al-Aqsa Mosque in the Old City of Jerusalem are among the most important Muslim sacred sites in the world (alongside Mecca and Medina in Saudi Arabia). Jerusalem is also home to the Wailing Wall (otherwise known as the Western Wall or Buraq Wall to 
Muslims), which is now the only surviving structure of the Herodian Temple, and thus the holiest site in Judaism. At the end of the seventeenth century, the Muslim population was significantly higher than the incoming Jewish migrants, but the demographics changed radically after Imperial Britain moved to fill the vacuum left behind by the Ottoman Empire.

In 1903, the British offered the territory to the Jewish people as a homeland and refuge from persecution; this was known as the "Uganda Scheme" but was rejected by the Zionist Congress. (The Balfour Project 2016: 1). This sympathy for the Jewish nation was aided by the presence of substantial Jewish communities in Russia and the US, swinging international public opinion toward the cause supported by the US (The Balfour Project 2016: 8 ). With the outbreak of war between Great Britain and Turkey, the idea of a Jewish nation became entirely plausible. The British passed the "Balfour Declaration," mandating the creation of a Jewish homeland in Palestine. By 1914, there were 60,000 Jews in the area, in comparison to the 683,000 resident Arabs, with increased immigration from Europe (Beinin and Hajjar 2014: 2). The idea behind this was to provide Jews with a refuge from persecution, as well as a place for homeless Jewish people that would prevent their assimilation into other cultures (Balfour Project 2016: 3). Naturally, this support empowered the Jews, but it also enraged the Arabs and resulted in major armed conflict between the two groups in the period between 1920 and 1921. Due to immigration, land purchases and land settlement, the growth of Jewish settlements threatened the Arabs to the extent that violence became common place. By 1928, the communities began to clash over the religious sites in Jerusalem, specifically the Western Wall and the plaza about the Wall known as the Temple Mount, home to two Israelite temples. This place is sacred to Muslims, who call it the Noble Sanctuary, and it hosts the Al-Aqsa Mosque, believed to mark the spot of Prophet Muhammad's ascension to Heaven on a winged-horse (Beinin and Hajjar 2014: 3). By this time, what started out as an issue of immigration had morphed into a protracted conflict with ethnic, religious and territorial dimensions. Hitler's rise in 1933 brought immigration to great heights, with a corresponding increase in resistance resulting in the Arab Revolt (1936-1939), suppressed by Britain with the help of Zionist military. By 1945, Britain had referred the problem to the UN, with 1.26 million Arabs and 608,000 Jews settled in the area and the latter owning about $20 \%$ of arable land (Beinin and Hajjar 2014: 4).

Much to the annoyance of the Arab-speaking world, the UN proposed and voted in a plan that sought to divide Palestine into two states in 1947, with the larger portion (56\%) going to the Jewish nation, and the smaller 
portion (43\%) allocated to the Palestinians. The Arab states and the Palestinian Arabs rejected this plan, and in their eyes, Jewish statehood had no legitimacy at all. By May 15, 1948, the British evacuated Palestine, and the State of Israel was proclaimed, sparking the First Arab-Israel War (1948-1949) with Israel expanding beyond its borders. This created an exodus of refugees from Palestine- owing to both the conflict and more so to the expulsive actions of the Jewish military (Beinin and Hajjar 2014: 5). Only about 150,000 Palestinians remained in the area that became the State of Israel, and they effectively became second-class citizens in a state defined by both religious and ethnic identity. By 1949, the end of the Arab-Israeli War saw the Israelis capture about $60 \%$ of the land initially allocated to the Arabs under the Partition plan, Jordan ruled the West Bank, and Egypt occupied the Gaza Strip. The conflict between Israel and the Arab states from without and within Palestine escalated throughout the 1950s and 1960s. In 1956, Egypt closed the Straits of Tiran to Israeli shipping and nationalized the Suez Canal, effectively blockading Israel. The Israelis captured the Sinai Peninsula and Gaza Strip and were pressured by the US and UN into accepting a ceasefire, with the USSR threatening to intervene on behalf of the Egyptians (BBC July 26, 1956). This episode saw the rise of Nasser as the president of Egypt and the hero of the Arab world when he resisted the French and British then assisting Israel. It also saw the rise of Yitzhak Rabin, a young military prodigy who eventually became the Israeli prime minister. The Six-Day War in 1967 occurred after Egypt expelled UN peacekeepers and moved troops into the Sinai, instating a blockade of the Israelis, who were simultaneously subject to constant harassment via the guerilla warfare waged for years by the Palestinians from Syria territory. Israel launched a surprised attack, destroying most segments of the Egyptian, Jordanian and Syrian air forces. By the end of the Six-Day War, the landscape of the Middle East had changed. Israel had captured the Sinai Desert from Egypt, the Golan Heights from Syria and the West Bank and Jerusalem from Jordan (Bowen 2017). This war hardened Palestinian resolve to revolt against Israel, as the latter had become a de facto occupying state in what was previously Palestinian territory, continuing its "resettlement building policy" in contravention of UN Resolution 242.

The 1973 Yom Kippur War, led by Egypt's Sadat, was waged to recover all territories taken by Israel after the 1967 War and to prompt Israel to achieve a just, peaceful solution to the Arab-Israeli conflict (Bean and Girard 2001: 4-6). Assad, however, wanted to reclaim the Golan Heights, particularly as Syria was armed with Soviet weapons. Despite this, Israel's military performed exceptionally well and was able to push the Arabs back. 
Hitting back with the Oil Embargo led to US intervention to ensure oil supplies. This led to a mutual ceasefire, and the beginning of peace talks. By this time, the role of the US and USSR in the conflict had become clear-they were both stoking regional actors to confront each other, thereby becoming two of the largest geopolitical sponsors in the Middle East. The UN passed Resolution 242 and it was adopted in the aftermath of the Six-Day War, attesting to the "inadmissibility of the acquisition of territory by war and the need to work for a just and lasting peace in the Middle East" and calling for the "withdrawal of Israeli armed forces from territories occupied by recent conflict." Palestinians had always been outraged by Israel's violation of the initial Partition plan, taking $78 \%$ of historic Palestine when only allocated $55 \%$ of the land.

Thus, the question of the Palestinian identity and statehood has been defined by a series of escalating conflicts and uprisings (most significantly the 1967 Six-Day War, the 1973 Yom Kippur War, the First Intifada of 1987, the Second Intifada of 2000, and the rise of Hamas). The relationship between the Israelis, the Palestinians and the Arabs has become intricately linked to the question of territory and security for all nations involved. The governments of Jordan, Syria and Egypt, however, have had differing positions on Palestine and policy toward Israel. Suffice to say that after the wars, Jordan and Egypt were amenable to reaching an agreement of coexistence with Israel, more so than the Syrians, and thus their policies toward the Palestinians weren't particularly consistent or united. By 1964, the Palestine Liberal Organization (PLO) was founded. It was recognized as the sole legitimate representative of the Palestinian people, with observer status at the UN beginning in 1974. Since its inception, the PLO has dedicated its existence to the liberation of Palestine through armed struggle. Consequently, both the State of Israel and the US (since 1987) ruled the PLO to be a "terrorist organization" until the Madrid Conference of 1991. By 1993, even though the PLO reached a consensus with Israel to recognize the two-state solution, mutual violence has continued unabated until today.

US intervention in the Middle East began in earnest with the end of the Second World War. The Truman administration's Middle East policy was defined principally by US concern for continued access to petroleum, the overarching danger of the Soviet threat and concern for the nascent State of Israel. Even though the US stayed neutral in the 1950s, by 1962, Washington was beginning to supply Tel Aviv with air defense systems, such as the Hawk anti-aircraft missiles, via West Germany, as it suspected that the Soviets were arming the United Arab Emirates and Iraq. In order 
to entice Jordan away from the Soviets, the US began arms sales to both Jordan and Israel as "balance" (US State Department Memo, March 11, 1965). By the end of the 1967 War, US restraint on weapons sales eroded as Washington firmly believed that the USSR was arming the Arab states, inciting the Palestinians against the State of Israel. Even though the US continued to supply both sides in order to prevent development of the Arab-Soviet relationship, this became untenable by the early 1970s. US interests in supplying Israel escalated exponentially from just fighter jets to all sorts of armaments (codename Nickel Glass) when the Soviets supplied the Arab states in a large-scale manner at the start of the Yom Kippur War (Dunstan 2003: 67). The state of tensions abated with the disengagement agreement signed in 1975. Throughout the Carter and Reagan administrations, the US-Israel relationship improved overall. The relationship was formalized through the signing of the 1981 Strategic Cooperation Agreement between Israel and the US, the conduct of joint military exercises in 1984, and the granting to Israel of the status of NATO ally in 1987. Such an unprecedented assurance allowed the US to establish a dialog with the PLO in 1988, continuing the work of the Carter administration's pledge to establish the Palestinian homeland. The first Bush administration encouraged the Israelis to continue dialog with Palestinians, urging both parties to accept the territory for peace principle and the fulfillment of the Palestinian people's rights. The Bush administration was finally able to bring the parties to the table at the Madrid peace conference, laying the basis for subsequent engagement. President Clinton was able to bring about what looked like permanent peace with the signing of the Oslo Accords by Yitzhak Rabin and Yasser Arafat. However, with the assassination of Rabin, and the beginning of the resettlement policy by Israel, the agreement quickly fell apart. From the events of September 11 to this day, peace in the Middle East looks increasingly fragile, as religious and ethnic religious tensions increase on a daily basis to the extent that Haass has suggested we are witnessing a new Thirty Year's War in the region.

\section{Japan's Involvement in the Arab-Israeli Conflict}

Japan's engagement with the Arab-Israeli conflict had its genesis in the immediate aftermath of the 1973 war (Halloran 1973). Japan was at the height of its postwar economic recovery efforts. In order to secure a constant access line to Middle Eastern energy and to provide for stable 
and long-term growth, Japan was keen to facilitate some kind of peace talks between the two sides. This caused Japanese policy to align with public sentiments sympathetic to the Arabs, and reassured the Japanese business community concerned with the 1973 Oil Embargo. Officially, the Japanese government's position broke ranks with that of the US and stipulated principles that spelled out Tokyo's position (Kuroda 2001: 106-110) on the issue as the basis of conflict. Named after Chief Cabinet Secretary Susumu Nikaido, the principles outlined in support of UN Resolution 242 were:

1. Inadmissibility of the acquisition and occupation of territory by force

2. Withdrawal of Israeli forces from all the territories of all countries occupied in the 1967 War

3. Respect for the integrity and security of the territories of all countries in the region and the need for guarantees to that end

4. The recognition of and respect for the legitimate rights of the Palestinian people in accordance with the Charter of the United Nations in bringing about a just and lasting peace in the Middle East

Tokyo expressed that it would observe the situation and reconsider its relations with Israel should the need arise, against which Tel Aviv strongly protested. This is somewhat at odds with the position of the US, particularly with regards to the characterization of the PLO's explicit methodology of armed struggle against Israel as terrorism, and only something that was eventually accepted during the Carter and Reagan administrations.

Prime Minister Masayoshi Ohira remarked that "Japan understands that the right of self-determination of the Palestinian people includes the right to establish an independent state," with Chair Yasser Arafat being invited to Tokyo by a Diet group in October 1981 (Naramoto 1991: 80). However, this was adjusted in the 1980s when Japan decided to strengthen its ties with Israel, given that there was an oil glut and that its relationship with the Arab states had been established by then. Arafat was officially invited by the Japanese government in 1989 and met with Prime Minister Toshiki Kaifu. Tokyo, however, stopped short of establishing direct economic exchanges or sending supplies because the PLO was not considered a state (Naramoto 1991: 81).

Nevertheless, Japan also reached out to the Israelis during this period, with an invitation to Israel after Arafat's visit in February 1990. This 
occurred two years after Foreign Minister Souseke Uno's visit to Israel, being the first cabinet level official to visit the country since the establishment of bilateral relations in 1952 (Deseret News, July 4, 1988). The PLO then requested that Japan lobby the US to compel the Israelis to be brought to the negotiating table. Arafat's visit was ostensibly held at ministerial level and represented a change to previous positions in which Japan deemed that no change would occur in bilateral relations unless there was an improvement in the peace process (Naramoto 1991: 81). Tokyo believed that it was important to have a "positive balanced relationship" with both the Palestinians and the Israelis. Like the US, Tokyo sought to build a "balanced" relationship with both. From a Palestinian perspective, this meant that Tokyo began to adopt a more proIsrael (or a more pro-US) policy, even though government policy was premised on UN Resolution 242 and the principles outlined in the 1973 Nikaido statement. By and large, the public interest in the Middle East waned over the 1980s. According to a survey conducted in the 1980s by the prime minister's office, $30 \%$ of the respondents noted the Middle East as a region that concerned them, but by 1986 this number had dropped to $9.5 \%$, only to rebound after the Gulf War (Naramoto 1991: 84). Most pertinent was the finding that public opinion was against the disbursement of USD 9 billion to fund the war effort.

The demise of the USSR ushered in an era where local political dynamics were less politicized by the dynamics of the Cold War, but at the same time, it also meant that the US was less prone to behaving in a multilateralist manner than the Europeans, Japanese and Russians. This, however, is somewhat mitigated by the fact that both the Arabs and Israelis grew increasingly vulnerable and reliant on the US, enhancing the ability of the US to serve as the "honest broker" (Miller 1997: 103-142). Through the careful cultivation of Jordan's King Hussein and Egyptian President Mubarak, President Bill Clinton was able to successfully bring Yasser Arafat and Yitzhak Rabin to conclude the peace agreement. Even though the US had been in the main driving seat of the peace process for decades, the Oslo Accords signed in Washington (1993) and Taba in Egypt were one of the most fundamental achievements to date. The Accords are a result of the Oslo process by which both the Israelis and the Palestinians agreed to a peace treaty in the spirit of UN Resolutions 242 and 338, aiming to realize the vision of the "right of the Palestinian people to selfdetermination" (Gadzo 2017). Up to this point, the US had been principally responsible for most of the direct peace initiatives in the Middle 
East, investing huge amounts of money, effort and prestige into the peace process (Touval 1982). The Oslo Accords were a culmination of five decades of diplomatic efforts. Despite the awarding of the Nobel Peace Prize to Yasser Arafat, Yitzhak Rabin and Shimon Peres in 1994, the peace did not last. With the assassination of Yitzhak Rabin and the changes of domestic political leadership in Israel, the peace process was scuppered. The US has not been able to prevent the increased populating and settlement of East Jerusalem, the forcible removal of Palestinian families (Russian Times, Feb 8, 2014), or the securitization of critical cultural sites in Jerusalem, ${ }^{2}$ accentuating and reflecting the emotional conflict between the Arabs and the Jewish nation. The Mount is considered to be the third holiest site in the world, after Masjid al-Haram, (the Grand Mosque in Mecca); Al-Masjid an-Nabawi (the Mosque of the Prophet), and Al-Aqsa Mosque (the furthest mosque) which includes al-Aqsa congregation mosque and the Dome of the Rock. Collectively, until these "final status" items are resolved, ${ }^{3}$ the gulf between the two nations remains insurmountable. In particular, the continued settlement in the West Bank, with a good portion of Jewish settlers in East Jerusalem (the future capital of the supposed Palestinian state), undermines any discussion of a two-state solution of the question.

Japan's contribution has been relatively insignificant compared with that of the US at this point, as it has focused on supporting US efforts principally through the disbursement of aid and developmental assistance. Even though Japan and other countries have tried to play a more active role (Lam 2009), they are unable to sidestep the US as it has shown little interest in allowing any other countries to intervene in the peace process, even in the case of Europe or Japan. This pivotal position allows the US to have exceptional access and influence over all actors and allows Washington to continually exploit its positional power in the region.

\footnotetext{
${ }^{2}$ For example, the Temple Mount is the primary site which is at the core of Judaism, Christianity and Islam. The site is known as: Haram al-Sharif in Arabic and Har haBayit in Jewish (Dumper 2014).

${ }^{3}$ The items are (1) security, (2) borders, (3) refugees, (4) Jerusalem and (5) mutual recognition and end of conflict and claims. For a succinct explanations of these concerns, please see "The Final Status Items for Israeli-Palestinian Negotiations: Challenges and Complexities", February 7, 2014, available at: http://www.aipac.org/ /media/ Publications/Policy\%20and\%20Politics/AIPAC\%20Analyses/Issue\%20Memos/2014/ IssueBriefPeaceProcess.pdf
} 
Washington has always shown exceptional support for Israel for a variety of reasons: sympathies for the Jewish nation stemming from the Holocaust; the power of the Jewish lobby in the US (Bard 1991); maintaining a central strategic position in Middle Eastern affairs; securing one of the largest arms sales markets; and most importantly, a genuine belief that it alone can secure peace in the region. Despite this, US support for the Israelis has always been challenged by other equally exigent priorities that are competing for funding and strategic attention in both the administration and in Congress - from Iraq to Yemen, from Afghanistan to Iran. The War on Terror might have made things worse, as the rise of Al-Qaeda and ISIS subsequently has led to conflict that has radically polarized the already divided Middle East.

\section{The Need to Revamp Japan’s Peacebuilding Strategy}

Since the end of the Cold War, Japan's more pro-Arab policy has shifted to more pro-US positions over time. This can be explained by international structural change and powershift, in part due to a decline in Arab unity and in part because of US hegemony (Miyagi 2011: 9-32). Notwithstanding this, it is erroneous to assume that Japan's national interests and US national interests coincide completely. While the US and Japan share an interest in securing access to oil (hence the propensity to support the Arabs at some level), and at the same time ensuring that the Jewish people are protected (hence the pro-Israel sentiments), Tokyo is not involved in arms sales and has a genuine interest is advocating an agenda of peace between the warring nations because of its pacifist culture.

Japan has increased its participation in the peace process since its inauguration in Madrid in 1991 and has worked alongside the major powers of the US and the EU to create frameworks for regional cooperation. Tokyo's strategy is to co-sponsor developmental projects, engage in dialog and administer aid to support US efforts. The aim of this is to create and foster economic conditions that can enable improvement of basic services and population recognition of the importance of building long-term peace. Japan in particular believes that without peace and economic vitality in these countries, it will be quite difficult to achieve peace in the Middle East on a larger scale. Beyond bilateral arrangements, Japan is also an active supporter of the Middle East and North African Economic Conferences (1994), Amman (1995) and Cairo (1996). 


\section{Fostering Better Socio-Economic Conditions}

Japan has co-organized multilateral negotiations and working groups since the January 1992 Moscow Conference, including: (1) the Upper Gulf of Aqaba Oil Spill Contingency Project (2) Project to Combat Desertification (EWG) (3) Tourism Workshop (4) support for the establishment of the Middle East Desalination Research Center. Additionally, Japan has also provided a substantial amount of economic assistance to the Palestinian Authority (Inbari 2011) and also to the countries involved in the peace process-namely Egypt, Jordan, Syria, ${ }^{4}$ and Lebanon.

According to Japan's Egyptian Embassy, Tokyo, in utilizing the Japanese Grant Scheme, has implemented important projects such as the Cairo University Pediatric Hospital, the Cairo Opera House, Suez Canal Bridge, and the Water Supply and Sewage Upgrading Project. Up until fiscal year 2013, Japan had provided a total of JPY 13 billion (USD 1200 million) to Egypt under this grant scheme. Funds provided in these schemes are not under any refunding or returning obligations. There is also grant assistance for grassroots projects (waste treatment systems, provision of medical services and projects aimed to improve employment rates in the country). Other forms of aid include cultural grant aid, technical cooperation and soft loans. ${ }^{5}$

In the case of Jordan, Japan has been at the forefront of aid efforts since 1974. As of 2004, Japan had provided a cumulative amount of USD 3 billion. In particular, Japan supports projects in the areas of water provision, environment, and health and medicine.

For Syria, prior to the War on the Islamic State, Japan focused its aid on five fields: (1) modernization of industries; (2) water resource use and management; (3) improvement of social services; (4) environmental protection and (5) promotion of regional stability in the Middle East. Like Egypt and Jordan, Japan's assistance to Syria includes a grant component: yen loans, grant assistance, grassroots human security projects and grants for cultural projects. Between 2001 and 2009, Japan provided JPY 7919 million to Syria for various projects. In 2010, Japan funded projects aimed at improving Japanese language learning, ensuring the provision of a

\footnotetext{
${ }^{4}$ For more details, see: http://www.sy.emb-japan.go.jp/econcoop.htm\#grant

${ }^{5}$ See detailed write-up on Economic Assistance to Egypt by the Embassy of Japan to Egypt: http://www.eg.emb-japan.go.jp/e/assistance/grass_roots/20121018.htm
} 
mobile library, building orphanages and deaf-mute schools, and improving medical equipment and handicap transportation in Syria (Japanese Embassy in Syria 2018).

The approach taken by Japan toward peace has been a comprehensive one. It fuses the regular elements of an overseas development assistance program with civilian components of peacekeeping. Along with the US and the EU, Japan is one of the largest donors to the Palestinians today. Tokyo has provided the Palestinians with generous assistance through a wide variety of programs. ${ }^{6}$ It has invested and tried to promote a structure for a viable future Palestine state; aimed to improve financial conditions; pushed for the strengthening of the private sector in Palestinian territories; provided assistance to refugees in Lebanon, Syria and Jordan; and disbursed food aid throughout the territories. Since 1993, Japan has provided USD 1.47 billion in aid to the Palestinians. ${ }^{7}$ After the peace process initiated by the Clinton administration, Japan pledged a total of USD 2 million, making it the third largest donor to the Palestine cause after the US and the EU. Admittedly, Japan first made the donation under pressure from the US, but nonetheless, it appears that Japan has actively lobbied on behalf of the Palestinians whenever it has been able to. Through its humanitarian and developmental assistance, Japan hopes to facilitate the governance aims (institution-building; improving the lives of Palestinians; building infrastructure) of the Palestinian Authority in order to give it legitimacy and viability and enhance the peace process.

By 2004, under the "Roadmap for Japanese Assistance to the Palestinians," Japan had given the Palestinians a sum that amounted to USD 760 million. With the election of US-backed candidate Mahmood Abbas as the head of the Palestinian Authority, Japan provided an additional USD 60 million. Even with the success of Hamas in January 2006 in Palestine's parliamentary elections, and a Hamas dominated legislature hostile to the US, Japan pushed through with the promised assistance.

While this might be interpreted as a "move" independent of the US, this might not necessarily be the case for several reasons. First, if Japan rescinds the aid, Japan would lose all its credibility in any work done with the Palestinians.

${ }^{6}$ See Japan's foreign ministry factsheet on Japan's aid to the Palestinians, November 2010 , http://www.mofa.go.jp/announce/announce/2010/11/pdfs/112402.pdf

${ }^{7}$ Press release, Representative Office to Palestine Authority of Japan, October 28, 2014; available http://www.ps.emb-japan.go.jp/PressRelease/PressRelease2014/n28October. pdf 
Second, it would only embolden the hardliners among the Palestinians and improve the prospects of Hamas politically because it would show that any US allied country would only back US-endorsed regimes, but never Hamas. Third, it would damage Japan's reputation irreparably as it would be perceived as a US lackey in the region. Lastly, if Japan pulled back its funding from the Palestinians, it might bring about greater problems in the Middle East peace process. It is not only therefore in Japan's interests but also in the interest of the US for Japan to keep funding the Palestinian Authority (Miyagi 2008, 2014).

One of the main pillars of Japan's approach to the Arab-Israeli conflict is Japan's concept of the "corridor for Peace and Prosperity." Japan has indeed exhibited an interest in playing a greater role in the region, hosting confidence-building conferences in 2003 and 2004, and once again in 2007. As reported by Gallup, during the May 2003 conference, Japan wanted to "explore ways in which Japan can contribute to peace," and in 2005, Prime Minister Junichiro Koizumi told Kyodo News that "Japan can provide support and cooperation in a different way from the US and Europe" by operating from a more "independent" position than the current players. ${ }^{8}$ In 2007, Japan attempted to rope in key players in a peace process, getting them started on a "non-political" ground-level project with low stakes but important functionalism. Japan proposed its "Corridor for Peace and Prosperity", comprised of an agro-industrial park in the West Bank meant to help build the Palestinian economy (Reuters, March 15, 2017).

Tokyo has cooperated with local and international governments to design and build the Jericho Agro Industrial Park. The facility draws its workers from the Palestinians living in the region, and engages in agriculture or industrial activities to help drive the region's economic growth. For example, local entrepreneurs grow and process vegetables and fruits (tomatoes and oranges) on a commercial scale. These are distributed locally and exported to Jordan. The park also has helped local entrepreneurs to establish various small scale manufacturing operations, such as a factory producing wipes (tissues) for the region, or health supplements made from olive tree leaves. Other Japan-financed business includes Al Masra and Dates Kingdom, with the former producing soft fruit-flavored beverages, and the latter processed date products (EUEA 2018). Japan has supported the financing of the park (via ODA and JICA),

${ }^{8}$ Ibid. 
ensured park security and shared technical expertise in training the workers. Japan also helps with infrastructure improvements such as roads being built to facilitate trade and transfers over the Jordanian border, which is located a few kilometers away. The park will provide access to electricity and water, which is difficult for the Palestinian entrepreneurs to source. A video released by the Japanese Prime Minister's Office in July 2018 , showed that approximately 200 people have found employment in the park, with an estimated 3500 people potentially to benefit from work opportunities in a few years' time (JPMO 2018). This park, conceived during the Koizumi era, has now materialized under Prime Minister Abe's tenure. Japan hopes that this "Corridor for Peace and Prosperity" initiative with the Palestinian Authority, Israel and Jordan will invite investment, create employment and facilitate exports to international markets. As Takeshi Okubo, Japanese Ambassador for Palestinian Affairs has said, this project symbolizes hope, peace and a better future for the people in the region (JPMO 2018). 9 Deeply embedded behind this thinking is Japan's subscription to the idea that Palestinians should be able to take steps to build a viable economy in order to materialize Palestinian statehood (Bryen 2000). To this end, Japan has also supported the main regional players directly affected by the peace process (Egypt, Jordan and Syria) through grant aid, loan aid, technical assistance and infrastructure projects, which shows the influence Japan could have, not just with Palestinians but with Arab countries as a whole. ${ }^{10}$ Japan has also contributed enormously to supporting women and children throughout the conflict. For example, in August 2014, the Japanese government committed USD 1 million toward providing fresh water and sanitation for the relief of 285,000 Palestinians, over $50 \%$ of them children staying at 90 camps and 19 schools. This number was dramatically revised in 2018, as the Japanese government increased funding to help Palestinian children to USD 4.5 million (UNICEF March 4, 2018). ${ }^{11}$

\footnotetext{
9 "Japan's stance in the Middle East," Japan foreign ministry website, http://www.mofa. go.jp/region/middle_e/stance.html

${ }^{10}$ Reuters, March 15, 2007, cited in "Israel, PA, Jordan agree to build joint agro-industrial park in West Bank," http://www.haaretz.com/news/israel-pa-jordan-agree-to-build-jointagro-industrial-park-in-west-bank-1.215610

11 “UNICEF Welcomes Japan's US\$4.5m in support of Palestinian Children," https:// www.un.org/unispal/document/unicef-welcomes-japans-us-4-5m-in-support-of-palestinianchildren-press-release/
} 


\section{Japan's Undisputable Credentials as a Peacemaker}

Japan's efforts seem to be capped at playing supporting role to the US. The most important aspects of enforcing peacebuilding, beyond placing peacekeepers in the Golan Heights, are not high on Tokyo's priority list. Efforts aimed at improving interactions between the Israelis and Palestinians appear to be elusive to Japanese diplomatic efforts. Does Japan's inability to play a greater role in the Middle East peace process stem from the fact that it lacks both the experience and capacity to do so? At first glance, many analysts do attribute it to a lack of experience. ${ }^{12}$

Traditionally, aside from the US, there have been three candidates that are most suited to play an enhanced role in the mediation of the ArabIsraeli conflict. They are the EU, the Scandinavian countries and Japan (Saad and Crabtree 2007). For historical reasons, including colonial history, both the Arabs and Israelis do not have a high preference for intervention by the EU. Additionally, the members of the EU have different interests and positions on many issues of foreign policy, which often complicates rather than facilitates the peace process (Nye 2014). Beyond this, as the democratic allies of the US, it is striking that they are excluded from the peace process (Miller 1997: 131). Not many other countries have actually tried to play an important role in the mediation of the problems between the Arabs and the Palestinians. Tokyo, however, has shown itself to be remarkably adept at peacebuilding efforts in other regions, such as Southeast Asia. Interviews with Middle Eastern academics concerned with the peace process revealed that Japan's weakness comes from the fact that Tokyo is being perceived as "lacking experience." It is, however, not difficult to understand why Japan does not have the requisite "experience" in the region, as peacebuilding efforts have largely been spear-headed by the US. Having said this, experience is not entirely necessary as there are other candidate countries who have played a relatively successful role in peacemaking with little experience, such as Norway.

The second factor is perhaps Japan's capacity. Even a country as strong as the US often finds itself as impotent as anyone else when it comes to influencing the Jewish state. According to Israel's famous defense minister Golda Meir, "Our American friends offer us money, arms and advice. We

\footnotetext{
${ }^{12}$ Personal communication with three academics from Israel who study Japan or the Middle East peace process, who gave the author this impression on three different occasions.
} 
take the money, we take the arms and we decline the advice" (Quoted in Shlaim 2001: 316; 401-402). The US, despite its profound ties with Israel, has on more than one occasion found itself ostracized from Israel's decision-making process. If a power such as the US has not made headway, then surely one would assume that Japan might not be able to do so. The issue, however, hinges on the question of the impartiality of the country in question. As the largest arms supplier to the State of Israel, the US also sells arms to select Arab countries. In this pivotal position, the militaryindustrial complex located within the US actually stands to gain from conflict. Japan, on the other hand, has no such vested interest.

Due to the history of two oil shocks and the hostility that Japan has faced previously from the Arab states over its professed neutrality, Japan has sought to cultivate closer ties with the Arab-speaking world by becoming one of the few industrialized nations to follow Arab demands to boycott Israel (Bakshi 2014). The harsh actions of the Israeli military have somewhat galvanized public support for the Arab states and have swayed Japan to the side of the Arabs. This still holds true today, as the use of force against the Palestinians generally does not go down well with the Japanese public. Conversely, because of its somewhat lackluster economic relations with Israel, Japan does not have the same sort of economic clout it has with other countries necessary to be able to influence the internal politics (Waage 2007: 157-156). ${ }^{13}$ However, because Japan has been perceived as pro-Arab, many Israeli officials tend not to view the country as neutral. Just as the EU would have to establish political goodwill with the Palestinian state, Japan would have to do the same with the Israeli government.

The fact that Japan does not carry a large stick around like Uncle Sam might be advantageous to this situation. Even though it has donated generously to the Palestinian cause and played an invaluable developmental role in the Arab world, the Arabs have been accustomed to Japan's

\footnotetext{
${ }^{13}$ However, this is not necessarily a deal breaker for Japan's future as a facilitator or mediator in the Arab-Israeli conflict, it just puts Japan at a disadvantage as Israel rather than the Palestinians have greater power in this relationship. One of the main reasons that the Norwegians were able to successfully broker the 1993 Oslo Accords was because the Norway-Israeli relationship was and still is extremely close, and Norway recognized then that goodwill from the Israelis was essential for the talks to move forward. Likewise, partly because of this relationship, the Israelis were persuaded to move forward with the concessions to the Palestinians. This was done independently of the 1991 Madrid framework the US had set up for the peace process.
} 
relatively inexperienced and unforceful role in the Arab-Israeli peace process. At the same time, the intricacies of the peace process not only require a genuine and altruistic player but also one with exceptional clout, who is savvy in international politics. The confidence-building conference is an attempt by Japan, which relies heavily on Middle Eastern oil, to play a mediating role in the regional peace process. Japan has always appeared to defer to the US on the question of the Arab-Israeli conflict. This is unfortunate as Japan has the necessary credentials and is equipped to mediate in the dispute.

Japan possesses unique credentials to promote peace in the Middle East for several reasons. Japan's track record of embracing pacifism (drawn from the constitution) is an extremely important source of inspiration envied by many Arabs and Israeli intellectuals. Even though the domestic narrative today focuses on the normalization or rejuvenation of Japan through the rewriting or modification of its constitution, by and large, the impression in the region is that Japan is a country where pacifism still reigns. Second, Japan has little to do with the origins of the region's problems and does not have a direct interest in the politics of the region except in the search for a lasting solution toward peace. Even though Japan has a tendency to favor the Arab nations in order to secure its energy supplies, Japanese diplomats understand that Israel has the upper hand in the conflict, and that no amount of pressure on Israel can move them to compromise on their positions should the Israelis not want to. With that starting point, whether Japan is more sympathetic to the Palestinian cause is immaterial, since no peacemaker can ignore Israel's upper hand in the conflict. Third, Japan has very few ties to Judaism and Islam and is not intimately tied to either of the ethnic groups in this dispute. Unlike the US, Japan does not have a strong Jewish lobby in Tokyo. The majority of Muslims in Japan are of Turkic and Central Asian origins. Fourth, Japan's official position supports a two-state solution in which Israel and a future independent Palestinian state would live side by side, all the while encouraging dialog and negotiation for the solutions to be materialized in the near future. ${ }^{14}$ Fifth, Japan is perceived to be an economic superpower with ambition for a permanent seat on the UN Security Council. Serving as the peacemaker might augment the building of a track record in this aim. Sixth, some commentators feel that Japan has earned a right to go its own

\footnotetext{
${ }^{14}$ Japan's Stance on the Middle East, Nov 24, 2010, Japan foreign ministry website: http://www.mofa.go.jp/region/middle_e/stance.html
} 
way from the US in its Middle East policy, particularly when it comes to the Middle East peace process (McGlyn 2008). Japan has been a loyal ally in the US War on Terror, sending MSDF ships to provide logistical support, as well as joint patrols in the Gulf. It funds a huge portion of the US presence in East Asia, and has for years provided financial resources, political backing and strategic support. Japan just needs to refocus its attention and clarify its role in the Middle East (Curtin 2004). Seventh, Japan has put in the time and resources to extensively cultivate ties on both sides; it holds the prerequisite patience and tact. As Nye (2014) argues, if you take the Palestinian and Israeli representatives from their native surroundings and put them in a "pleasant, remote Japanese hotel with a view of the Sea," they might find some common ground.

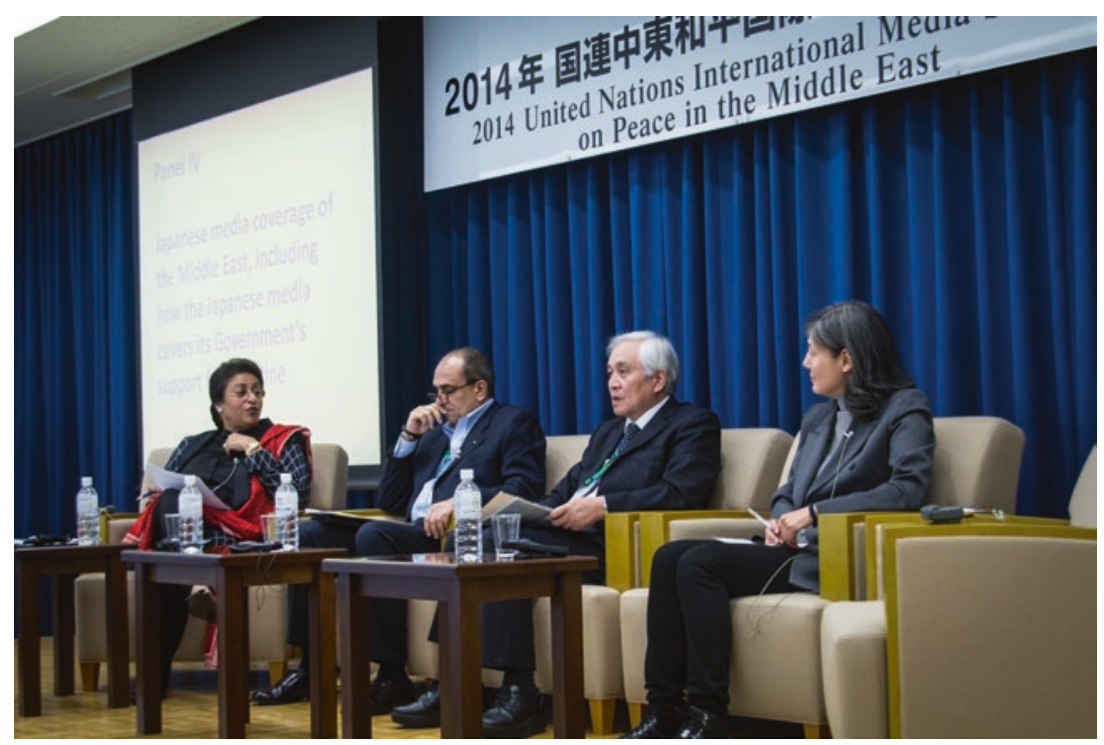

Photo: UN International Media Seminar on Peace in the Middle East in Tokyo. (2014 International Media Seminar on Peace in the Middle East, Sophia University, Tokyo, June 9-10, 2014, organized by the United Nations Department of Public Information in cooperation with the Ministry of Foreign Affairs, Japan. Photo: United Nations/John Gillespie, Attribution-share alike 2.0 Generic License (CC By-SA 2.0) https://www.flickr.com/photos/johnji/14415948003)

To that end, Japan has been doing some important work in this regard. It is uniquely placed to ensure that the cultural and socio-psychological 
work needed for reconciliation takes effect. Cultural exchanges reduce prejudice and demonization, encourage the idea that friendship across nations can take place during conflict, allow for the healing of political wounds, and enable the restoration of pride in traditional cultural heritage. Once this happens, it can be mobilized for national reconstruction and peacebuilding (Ogoura 2009). Ambassador Ogoura gives the example of a Japanese NGO that invited Palestinian and Israeli high school students to Hiroshima and enabled them to interact through football matches. It made this younger generation realize that it is possible for them to become friends and interact, and that their future interactions need not be tied to the fate of preceding generations (Ogoura 2009).

\section{Losing Sight of the Forest for the Trees}

So why is Japan not playing a larger role in the peace process? There are two aspects to this answer. First, Japan's domestic support for greater intervention in the Middle East is not strong. For the last two decades, Japan's strategic attention has been fixated on the rise of China and the implications this has for Japan. Much narrative is focused on the dispatching of military units (minesweepers, refueling vessels, troops in support roles) to various hotspots. Such deployments lend support to the US, provide good training opportunities for the JSDF, and socialize the Japanese people and Japan's neighbors to the idea of Tokyo "normalizing" its political and military status. Even though there is a certain measure of support among the Japanese people for Japan's fulfillment of international responsibilities, the support tends to dwindle when the question touches on whether precious resources such as money should be used, and the lives of Japanese troops put at risk. The inertia created by Japan's pacifist culture is strong because it is deeply embedded in the Japanese national identity. For many Japanese, pacifism is linked with democracy, or even seen as one and the same, even though they are conceptually different things. The resistance that the neo-conservatives embarking on constitutional amendment face today at the grassroots level stems from the fact that many Japanese citizens feel that what the Abe government is doing erodes their democratic rights and innately Japanese identity and culture. Even though the "rational" narratives about China and North Korea are put forth to assuage the electorate, it is still an uphill battle.

Second, and most importantly, is Japan's own conceptualization of its relationship with the US. The crux is that Japan's Middle East strategy is 
premised on the Yoshida Doctrine, which indicates that Japan should follow the lead of the US in strategic and foreign affairs. Tokyo took this to heart for most of the Cold War, particularly in the Middle East. For the most part, the "positive balance" policy that Japan has undertaken in the Middle East peace process is circumscribed by three important elements that the US has allowed Japan to partake in: political dialogs, confidence building, and the extension of economic assistance to the Palestinians (Curtin 2004; Inbari 2014). Japanese diplomats often have to work under US sponsored events, and Japanese aid or developmental projects are designated to complement US plans. In privileging the US-Japan alliance, Japan is forgoing the opportunity to carve out a more independent role for itself in the peace process.

Despite diplomatic rhetoric, the US has worked hard to ensure that no other power is able to become dominant in the peace process, including Japan. The Clinton administration was said to have been furious at Japan's attempt to play a more central role in the Arab-Israeli peace process, and every effort was made to ensure the US maintenance of a position of centrality in the peace process (Soetendorp 2002: 283-295). The US would have hated losing control of an issue as central to Middle Eastern politics as the Arab-Israeli peace negotiations. Beyond that it, it would not have tolerated the rise of another nation with potential to surpass US influence in Middle Eastern affairs. This, however, should not come as a surprise. Every country will strive to maximize its own interests in the region, even in the case of Japan. It therefore comes as no surprise that Japan's overtures to play a greater role in the Arab-Israeli negotiations, as well as in the Iranian nuclear issue, were rejected by none other than its close ally, the US (Schulze 2015). ${ }^{15}$

The onus for Japan to play a greater role rests on Japan's prioritization of its interests above its relationship with the US. This would include spelling out a greater role for itself as a "peace" state in the region, rather than seeing its role as being one of deference to and unconditional support of US policies. There are four main immediate impediments to improving

\footnotetext{
${ }^{15}$ This point is also reiterated by the various interlocutors whom the author has spoken to over the years. Most Japanese colleagues who articulated this view do not want to be identified, because there is a real fear that their careers will be affected. There seems to be a consensus that even with on-the-ground activities, Japanese groups are often given "guidance" as to what is permissible and what is not.
} 
Japan's position in the Middle East, and all these stem in part from the imperfect conceptualization of Japan's normalization and rejuvenation.

The first principal impediment is Japan's inability to foster an independent vision for Japan in the region and beyond. Despite the rhetoric and the official narratives, Japan has yet to reach a clear and welldefined goal for Japan's normalization and rejuvenation with regards to its policy outside the Asia-Pacific. The direction and tone of Japan's recent diplomacy certainly reflects a hint of desire to seek a foreign policy that maintains a streak of independence from the US, but a Japan that could possibly survive and thrive on its own is beyond the imaginary reach of most Japanese strategic thinkers. Certainly, the author is not the only one to feel strongly that Japan should conceptualize and articulate a clearer vision of its role to date, particularly in the Middle East. As one editorial argues, even though since 1993, Japan has contributed USD 1.7 billion to the Palestinians via programs that aid socio-economic development, there is a marked difference between official government policy and Japan's prime ministerial outreach (Cooper and Gover 2018).

Second, Japan has developed a culture of deference to the US alliance, and this has inhibited it from developing an independent and forwardlooking agenda with regards to its global strategy. This has consequently led Japan to allow its goals to be subsumed into US foreign policy goals and sensitivities rather than trying to harmonize their interests where possible and pursue its own interests when not. Cooperation with the US has therefore become a goal in itself rather than a means to spring-board to something greater. If Japan seeks rejuvenation as a global power, then it has to consider that there might be times when it has to speak beyond the confines of the US-Japan alliance. Prioritizing the preservation of the US-Japan security alliance and US goals in the region might not be in the best interest of the region. Most observers agree that deep down, at the protracted root of the conflict, is the fact that Israel illegally apportioned and annexed territories that belonged to Palestine at the onset of the conflict. The very fact that Japan supports UN Resolution 242 is indicative of this. Yet, no one has called upon the US not to support Israel or requested that the US enforce the requisite law on the State of Israel. Failure to act in the first place is the very reason why the conflict has grown to be so protracted.

Third, this essentially meant that even though one of the principal goals Japan has articulated in recent years is the promotion of peace in the international community, its ability to realize its potential as a peacemaker 
has been thwarted by its image as a country subservient to US foreign policy goals. While the idea of becoming a global power by relying on the "globalizing" US-Japan alliance might seem desirable to the neoconservatives in Tokyo, the question of whether or not it serves Japanese interests directly is something that needs to be considered. Take for instance how third parties might view this relationship. Today, the Israelis view Japan as extremely polite but utterly powerless over the Palestinians in terms of curbing the violence and improving Israel's homeland security situation, and in turn, the Palestinians may feel that as much as Japan might want to assist them, it has neither the influence to affect the settlements nor clout to enforce the peace.

Fourth, the lack of autonomy insofar as the peace talks are concerned is a facet that is remarkably absent from Japanese public narratives about its intervention in the Middle East. Instead, Japan's focus has been solely on peacekeeping and humanitarian assistance. In particular, these narratives relate to the "normalization" of Japan's security forces by enhancing their operational readiness and deployment capabilities. Unless the Japanese government decides to make this a priority and shift the debate from military to political rejuvenation, then Japan is unlikely to ever garner public support for this. A healthy discussion on the desired role of Japan in the peacebuilding process in the Middle East would be welcome. Japan has failed to do what it perhaps might be in the best position to dobecome a genuine peacemaker in the region. Achieving this requires Japan to adopt a higher profile and a more independent position from the US, something it may be reluctant to do. Japan's 2007 Peace Corridor initiative for common economic development is an interesting diversion for both the Arabs and the Israelis to come on board and jointly engage in an economic partnership, but it is unfortunately insufficient to promote peace between them. The strategy is a good one, shifting the focus from land deals, but it stops short of pushing the two sides to come together for some sort of more permanent peace.

In his second term, it is clear that Prime Minister Abe had also learned something important from his first stint as prime minister and from his predecessors' experience-from providing financial resources for the first Gulf War and JSDF deployments for anti-piracy deployments, to the Persian Gulf, Japan has been providing political, logistical and military assistance to the US. For Prime Minister Abe, it would therefore be wise for Japan, rather than US, to earn the recognition it deserves when it makes contributions. Consequently, in 2014, Prime Minister Abe offered 
Japan's support of USD 200 million in the War against the Islamic State of Iraq and Syria (ISIS), just days before the hostage crisis (which incidentally is the amount demanded by the hostage takers) (Schulze 2015). Translated to the neo-conservative's language, this means that in order to have the rejuvenation that Japan seeks, it might be necessary for Japan to refrain from seeking approval from the US, instead contributing to substantial direction and narratives as an independent nation seeking a greater role and status in the region.

\section{The Neo-Conservatives' Peacebuilding Efforts IN THE TRUMP ERA}

It is of no surprise that between 1993 and 2017, Japan provided USD 1.77 billion to Palestinian causes (Kabilo 2017). By the early 2000s, Japan had shifted its policy in the Middle East to take a more independent and proactive stance. Even though the Middle East, particularly Saudi Arabia (Cafiero et al. 2016), is critical to Japan's interests, the domestic media and political narratives have often underestimated the region's importance to Japan. But since this period of neo-conservative power acquisition, the region has become a "target" for Japan's reinvigorated foreign policy. In 2002, the Japan Institute for International Affairs (JIIA) released a white paper recommending several courses of action. One notable suggestion was that Japan should strengthen cooperation and build coalitions with regional partners beyond Jordan and Egypt, but also Saudi Arabia; that Japan should endeavor to expand the "Quartet" (US, EU, Russia and UN) in conjunction with Egypt, Jordan and Saudi Arabia. Other recommendations included the intensification of dialog and discussion on both sides at the Track 2 level, along with a strengthening of consultation. Most interestingly, the JIIA asked to develop a bilateral youth initiative to ensure future generations can co-exist, with JIIA indicating that they would help to develop history textbooks for both sides (JIIA 2002: 4-5).

Most of Japan's prime ministers have run under the motto of peace, pride and internationalism, and of the most commonly articulated policy platforms, "international contribution" was most routinely called upon (Le 2012: 21). This reflects the general socialization of Japanese prime ministers who grew up in a pacifist Japan that was content to do its part in the postwar San Francisco system, with seemingly little appetite for participation in global affairs or great power status. Yet, even when Prime 
Minister Koizumi first came to power, his immediate concern was Japan's economic progress, not foreign policy. In June 2004, when he decided to send JSDF forces to help in Iraq, there was a sharp drop in the cabinet approval rating from $54 \%$ to $40 \%$ (Shinoda 2007: 152-153).

One of the stimuli is undeniably China. Unlike Japan, which has historically been firmly entrenched in the Western Cold War bloc, China has long had historical interactions with the Middle East. During the Cold War, China maintained most if not all of its ties with the Middle Eastern countries. Today, China is now viewed as a major independent political power. All Middle Eastern powers are keen to cultivate relations with China as a major political power. This is as true for traditional US allies such as Israel and Saudi Arabia, as it is for rivals such as Iran or Egypt. The need to increase Japan's political weight (i.e. vis-à-vis China and the US) exists. This is particularly true as the US currently holds all the cards in bilateral dealings. From the perspective of countries such as Iran, Yemen or Palestine, China's role as a potential honest broker in regional problems is a particularly critical one, as many states do not see the US (or Japan) as ever having played an even-handed role. This is particularly important in an era where over the last 30 years, civil and proxy wars have become impossible to distinguish (Haass 2014). Eradicating Saddam Hussein's regime has led to a certain imbalance which Saudi Arabia, Iran and Turkey are eager to address. For China, the contentious Middle East represents a new opportunity for her to realize its One Belt One Road (OBOR) initiative by involving countries in the region. Beijing argues that as opposed to the US's desire to control the developments in the region via proxies and managed low-intensity conflict, China's OBOR vision promises developmentalism without control and connectivity without dominance.

China's grand vision has been met with skepticism and disdain from the US-led bloc. Since his first administration, Japan's Prime Minister Abe has appeared determined to meet the China challenge globally, and to that end Abe's vision of Japan offering these regions an alternative economic network ensures that nation-states are not enticed into, or entrapped in, a "China centric" economic network, ending up with an asymmetrical relationship with Beijing. In denying China an extended hinterland for a Beijing-style Marshall Plan, Japan, along with the US, is also preventing these countries from becoming economically (and somewhere down the line) politically connected with (and reliant on) Beijing. China's determination to promote the connectivity of the ancient Silk Road that runs overland from China through Central Asia to the Middle East has led to a series of "strategic partnerships" in eight 
countries, six of which are founding members of the Beijing-backed Asian Infrastructure Investment Bank (AIIB) (Zhao 2016). The Chinese factor is therefore an important motivating reason for Japan's keenness to take on a greater role in its Middle East strategy, particularly since Xi's proposal at the China-Arab States Cooperation Forum, where he emphasized that China will collaborate with the Middle Eastern states on a " $1+2+3$ " formula (Industrialization, Commercial Capacity and Concessional loans).

Prime Minister Abe's "proactive pacifism" strategy, put in place after the 2014 election, is precisely geared in this direction. By seeking to reinvigorate Japan's presence in the region, Prime Minister Abe is hoping that Japan will be able to counter China's grand plan and instead raise Japan's own profile in the region. Although there is no clear indication that China and Japan see each other's presence as a threat, it is clear that Tokyo does see the Chinese presence as something that needs to be watched very carefully.

On September 12, 2017, Japan's foreign minister met the Arab League and articulated the "Kono Principles," where the foreign minister promised that Japan will (i) drastically expand the intellectual and human contribution to peace and prosperity in the Middle East; (ii) invest in human resource development geared toward the promotion of peace and development in the region; (iii) put in enduring efforts to cultivate peace; and (iv) enhance political efforts in the Middle East. In sum, Japan continued to reiterate its commitment to the "Corridor for Peace and Prosperity," where Tokyo encourages and supports the independence of the Palestinian economy through regional cooperation with Palestine, Jordan and Israel. Japan also committed to help enhance the fruit harvesting economy and other agriculture in the region, also as well as the IT, AI and tourism in the region. Tokyo will continue to help realize comprehensive peace in the Middle East and expand cooperation on education and human resources development in the Arab League. Japan also promised to enhance political dialog in the region, not only on a bilateral basis, but also on a multilateral one, including strategic dialogs, promotion of reconciliation (e.g. between Qatar and Arab countries) and more facilitate open discussions on the incorporation of the Middle East into the "Free and Open Indo-Pacific Strategy." Lastly, Japan committed USD 25 million to new humanitarian assistance for Syria, Iraq and other countries (MOFA Japan, September 12, 2017).

By December 2017, Japan was still under criticism for being as helpless as ever after it joined 128 countries in support of a UN General Assembly resolution condemning the US decision to recognize Jerusalem as the 
political capital of Israel (Kabilo 2017). The criticism is leveled at Japan from both sides. The Arabs feel that even though Japan is a generous donor, it is unable to rein in Israel, particularly when the US maintains its protection of Israel.

Ironically, Jewish intellectuals and officials grouse about Tokyo being "unfriendly" toward Israel. Prime Minister Abe, while being tremendously generous and friendly toward both the Palestinians and Israel (Taylor 2015), is behaving in such a manner that is at odds with Japan's official policy thinking. From the perspective of some observers, particularly those from the Israeli camp, this resembles cognitive dissonance. In an editorial, two Jewish intellectuals complain about this:

The marked difference between Abe's positive engagement of Israel and the Japanese Ministry of Foreign Affairs' shortsighted and at times hostile political positions towards the Jewish state is confounding. One would be forgiven for thinking that the Foreign Ministry didn't get the memo from the Prime Minister's Office on Abe's new forward-thinking engagement with the Jewish state While the Japanese government is to be commended for decades of generous international aid, its March 2018 \$23.5 million aid package to the United Nations Relief and Works Agency for Palestine Refugees in the Near East (UNRWA) has been transferred to an entity whose Hamas-controlled teachers have allegedly been teaching Palestinian children with curricula that praise 'martyrdom' (read terrorism) and do not even show the State of Israel on a single map in any of the books. (Cooper and Gover 2018)

Despite these difficulties, there is a proverbial pot of gold waiting for Japan if it keeps plugging away with the peace process. As argued earlier, Japan's strategy to collectively engage the future generations of Israelis and Arabs is a wonderful exercise, particularly if these youths are transported out to various parts of Japan. Japan's relative neutrality, economic prowess, and proximity to the US have certainly helped with Washington's “tolerance" of its involvement in these matters. As Japan increases its engagement, it will provide a measure of balance to the peace process that the US perhaps cannot offer (Nikkei Asian Review 2017). Tokyo's attempt to invite Israel's leader to Tokyo for a 4-way summit in 2018 is a good example (JTA 2018). Japan, however, has to decide what kind of peacemaker it wants to be. While this is not a suggestion to encourage Tokyo to revolt against the US, it is important that Japan aims to become a fair, moderate voice that can call out its longtime ally when there are genuine grievances and wrong doings. There is certainly support for the 
fact that Tokyo could become a fair, impartial and effective peacemaker. There are three possible things Japan could do. First, Japan should try and transcend the "allowed" perimeters the US has set for it (encouraging reconciliation, enabling political dialog and enhancing socio-economic conditions for the Palestinians), to become an independent and moderate influence. One example is to rally for sanctions against Israel for breaking international laws such as the UN resolutions, or when it violates the human rights of Palestinians. Perhaps Japan does not have the power to accomplish this, but given the recent moves by the Trump administration to support Jewish settlements in Palestinian areas and recognize the embassy in Jerusalem, more can be done by Japan. As Japan builds coalitions to balance the excesses of its close ally, a possible and imaginative way forward is to work with China to build a different coalition and pursue an alternative peace process. There are few people in the world that are not aware of the tensions in the Sino-Japanese relationship, but a political partnership between the Asian giants might provide a sorely needed balance in the region. In the past, the Arabs could rely on the Soviets to moderate US adventurism in the region, but since the end of the Cold War, the US has had the main positional power and exploited it, exacerbating difficulties in the region. Working with China has the added bonus of boosting bilateral cooperation and building confidence currently lacking in Sino-Japanese relations. As the next chapter on anti-piracy missions outlines, it is not entirely impossible for China and Japan to collaborate. This gesture would certainly be appreciated by the Chinese and signal to both Israel and the Arab nations that Japan could transcend its traditional role as the ally and play the part of a peacemaker for the twenty-first century. Whether Japan succeeds or fails is another matter but having the legitimacy and credentials to be endorsed as an important political power in its own right certainly speaks to the prospects of achieving rejuvenation and attaining the goal of a "Beautiful Japan" through achieving peace in the Middle East.

\section{REFERENCES}

Bakshi, G. "Israel-Palestine Conflict - Need for a New Third Party Negotiator." Middle East Monitor, 30 Jan 2014, https://www.middleeastmonitor.com/ tag/israel-palestine-conflict/

Balfour Project. "The Balfour Declaration, November 1917", http://www.balfourproject.org/wp-content/uploads/2016/11/The-Balfour-Declaration. pdf 
Bard, M.G. The Water's Edge and Beyond: defining the limits to domestic influence on U.S. Middle East policy. Transaction Publishers, 1991.

BBC News. "1956: Egypt Seizes Suez Canal”, 26 July 1956, http://news.bbc. co.uk/onthisday/hi/dates/stories/july/26/newsid_2701000/2701603.stm

Bean, James W., \& Girard, Craig S. “Anwar Al-Sadat's Grand Strategy in the Yom Kippur War.” National War College Report, 2001, http://www.dtic.mil/dtic/ $\mathrm{tr} /$ fulltext/u2/a442407.pdf

Beinin, J., \& Hajjar, L. "Palestine, Israel and the Arab-Israeli Conflict: A Primer." Middle East Research and Information Project Paper, Feb 2014, https://www. merip.org/sites/default/files/Primer_on_Palestine-Israel(MERIP_ February2014)final.pdf

Bellamy, A., Williams, P.D., \& Griffin, S. Understanding Peacekeeping. Cambridge \& Malden: Polity Press, 2010.

Bowen, Jeremy. "1967 War: Six Days that Changed the Middle East." BBC, 5 June 2017, https://www.bbc.com/news/world-middle-east-39960461

Bryen, R. A Very Political Economy: Peacebuilding and Foreign Aid in the West Bank and Gaza. Washington D.C.: United States Institute of Peace Press, 2000 .

Cafiero, G., Karasikm, T., Miotto, C., \& Wagner, D. “Japan’s Important Role in Saudi's Vision 2030." Huffington Post, 29 November 2016, https://www. huffingtonpost.com/giorgio-cafiero/japans-important-role-in-_b_13334900. html

Cooper, A., \& Gover, T. "Japan has important role in Middle East buy must clarify it." Asia Times, 29 July 2018, http://www.atimes.com/article/japan-hasimportant-role-in-middle-east-but-must-clarify-it/

Curtin, J.S. "Japan seeks bigger Middle East Role: Economic Diplomacy." The Asia-Pacific Journal: Japan Focus, vol. 2, no. 12, 2004, https://apjjf.org/J.-Sean-Curtin/1984/article.html

Deseret News. "Role for Japan as Peacemaker ?" 4 July 1988, https://www. deseretnews.com/article/9455/ROLE-FOR-JAPAN-AS-PEACEMAKER. html

Dobson, H. Japan and UN Peacekeeping: New Pressures and New Responses. London and New York, Routledge, 2003.

Dumper, M. Jerusalem Unbound: Geography, History, and the Future of the Holy City. New York: Columbia University Press, 2014.

Dunstan, S. The Yom Kippur War 1973: The Sinai, p. 67. Osprey Publishing, 2003.

EUEA (European Union External Agency), "Japan provides two new contributions to the Jericho Agro Industrial Park incentives programme implemented by the EU", Press Release, 12 June 2018, https://eeas.europa.eu/headquarters/headquarters-homepage/46344/japan-provides-two-newcontributionsjericho-agro-industrial-park-incentives-programme_en 
Gadzo, M. "Palestinians speak out on Anniversary of Resolution 242." Aljazeera, 19 November 2017, https://www.aljazeera.com/news/2017/11/palestinians-speak-anniversary-resolution-242-171117092925628.html

Haass, Richard. "A New Thirty Years' War" Council for Foreign Relations, Commentary published on Project Syndicate, 21 July 2014, https://www.project-syndicate.org/commentary/richard-n\%2D\%2Dhaass-argues-that-the-middle-east-is-less-a-problem-to-be-solved-than-a-condition-to-be-managed

Halloran, R. "Japanese Caution Israelis on Ties." The New York Times, 22 Nov 1973, https://www.nytimes.com/1973/11/22/archives/japanese-cautionisraelis-on-ties-tokyo-hints-break-possible-if.html

Harrison, S., \& Nishihara, M. UN Peacekeeping: Japanese and American Perspectives. Carnegie Endowment for International Peace, 1995, https:// carnegieendowment.org/1995/10/01/u.n.-peacekeeping-japanese-andamerican-perspectives-pub-203

Inbari, P. "Japan and the Palestinian Authority: Foreign Policy and Economic Interest.” Jerusalem Center for Public Affairs, 4 March 2014.

Inbari, M. "Japan, the Middle East and the Palestinian Authority." Jerusalem Institute of Public Affairs, 2011, http://jcpa.org/japan-the-middle-east-andthe-palestinian-authority/

Ishizuka, K. "Japan's Policy Towards UN Peacekeeping Operations." In Mely Cabellero-Anthony \& Amitav Acharya, UN Peace Operations and Asian Security. Routledge, Oxford and New York, 2005, pp 56-72.

Japan Institute of International Affairs Middle East Peace Policy Study Group (JIIA MEPPSG). "Japan's Future Politics Towards the Middle East Process: Recommendations." Tokyo: JIIA, 26 July 2002.

Japanese Embassy in Syria. "Summary of Assistance to Syria," http://www.sy. emb-japan.go.jp/econcoop.htm\#summary

JTA. "Japan invites Netanyahu to four-way peace summit in Tokyo." The Jerusalem Post, 25 August 2018, https://www.jpost.com/Arab-Israeli-Conflict/Japaninvites-Netanyahu-to-four-way-peace-summit-in-Tokyo-520085

JPMO - Japan Prime Minister's Office, Video on "Japan's cooperation with the Jericho Agro-Industrial Park in Palestine”, 18 July 2018, https://www.youtube.com/watch?v=HP8KPijCEFE

Kabilo, G. "Risk-Adverse and Dependent on Oil, Japan tiptoes through the Middle East." Calcalist Opinion, 27 Dec 2017, https://www.calcalistech. $\mathrm{com} / \mathrm{ctech} /$ articles/0,7340,L-3728311,00.html

Kozai, S. "Japan and PKO; Japanese Experiences and its Policy." Journal for International Studies, Osaka Gakuin University, vol. 12, no. 2, 2001.

Kuroda, Y. “Japan's Middle East Policy: Fuzzy Nonbinary Process Model” in Miyashita, A. \& Sato, Y., Japanese Foreign Policy in Asia and the Pacific: Domestic Interests, American Pressure and Regional Integration, New York \& Basingstoke: Palgrave, 2001, pp 101-119. 
Lam, P. Japan's Peace-Building Diplomacy in Asia: Seeking a More Active Political Role. Oxford and New York, Routledge, 2009.

Le, T. “Assertive Peacemaking: Japan's Evolving International Role.” Western Political Science Association 2012 Annual Meeting Paper (WPSA Paper), Portland, Oregon, 22-24 March, 2012.

Leitenberg, M. The Participation of Japanese Military Forces in UN Peace Keeping Operations. Maryland: Center For International and Security Studies, University of Mary Land, 1996.

Maeda, T. The Hidden Army: The Untold Story of Japan's Military Forces. Chicago: Edition Q, 1995.

McGlyn, J. "With One Sentence Japan Cold Set the Stage for an Israeli-Palestinian Peace." The Asia-Pacific Journal: Japan Focus, vol. 6, no. 10, 2008.

Miller, B. "Greater Powers and Regional Peacemaking: Patterns in the Middle East and Beyond." Journal of Strategic Studies, vol. 1, no. 20, 1997, pp 103-142.

Ministry of Foreign Affairs, Japan, (MOFA Japan). Speech by Foreign Minister Kono at the first ever Japan Arab Political Dialogue, 12 September 2017, https://www.mofa.go.jp/files/000288921.pdf

Miyagi, Y. "Japan's Middle East Security Policy: Rethinking Roles and Norms." Ortadogu Etuleri, vol. 3, no. 1, 2011.

Miyagi, Y. Japan's Middle East Security Policy: Theory and Cases. Oxon, OX; Routledge, 2008.

Miyagi, Y. "Japan and the Middle East After the Arab Spring." IDE ME Review, vol. 1, 2014, pp 28-45, http://www.ide.go.jp/library/Japanese/Publish/ Periodicals/Me_review/pdf/201402_02.pdf

Naramoto, E. "Perceptions on the Arab-Israeli Conflict." Journal of Palestine Studies, vol. 20, no. 3, 1991, pp 79-88.

Nikkei Asian Review. "Japan seeks more active role in bring peace to the Middle East.” 24 August 2017, https://asia.nikkei.com/Politics/Japan-seeks-moreactive-role-in-bringing-peace-to-Middle-East2

Nye, D. "After the American century: Might Japan be the Broker to Negotiate Peace between Israel and Palestine ?" After the American Century, 18 August 2014, http://aftertheamericancentury.blogspot.com/2014/08/might-japanbe-broker-to-negotiate.html

Ogoura, K. "The Peacemaking Process has a cultural dimension." The Japan Times, 11 April 2009.

Russian Times Editorial. “Israel's destruction of Palestinian homes at five-year high - aid orgs" Russian Times, 8 Feb 2014, http://rt.com/news/israel-palestinian-destruction-aid-134/

Saad, L., \& Crabtree, Steve. "Israel/Palestine: Support for Potential Peace Brokers: EU, Japan appear more acceptable to both populations." Gallup News Service, 26 Jan 2007, https://news.gallup.com/poll/26290/IsraelPalestineSupport-Potential-Peace-Brokers.aspx 
Samuel, H. "The Future of Palestine." Memorandum to the Cabinet, January 1915, The National Archives of the UK, hereafter TNA, CAB 37/123/43.

Schulze, K. "Shinzo Abe's Middle East Ambition." Emerging Equity, 12 Feb 2015, https://emergingequity.wordpress.com/2015/02/12/shinzo-abesmiddle-east-ambition/

Shelter-Jones, P. "Peacebuilding as a Field of Joint Endeavor in the Japan-U.S. Alliance: The View from an International Organisations' Perspective", in Hoshino Toshiya and Weston S. Konishi, US-Japan Peacebuilding Cooperation: Roles and Recommendations toward a Whole-ofAlliance Approach, Joint Compendium Report published by Institute of Foreign Policy Analysis (IFPA) and Osaka School of International Public Policy (OSIPP), Osaka and Washington D.C., CreateSpace Independent Publishing Platform, 2012, pp 29-43, http://www.ifpa.org/pdf/peaceBuildingCompendium.pdf

Shinoda, T., Koizumi Diplomacy: Japan's Kantei Approach to Foreign and Defense Affairs. Washington: University of Washington Press, 2007.

Shlaim, A. The Iron Wall: Israel and the Arab World. New York, W.W. Norton \& Company, 2001.

Soetendorp, B. "The EU's Involvement in the Israeli-Palestinian Peace Process: The Building of a Visible International Identity." European Foreign Affairs Review, vol. 7, no. 3, 2002, pp 283-295.

Soeya, Y. "Japanese Security Policy in Transition: The Rise of International and Human Security." Asia-Pacific Review, vol. 12, no. 1, 2005.

Spiegel, S.L. The Other Arab-Israeli Conflict: Making America's Middle East Policy from Truman to Reagan. Chicago: Chicago University Press, 1985.

Suzuki, H., editor. The Middle East Turmoil and Japanese Response - For a Sustainable Regional Peacekeeping System. Tokyo, JETRO, 2013, http://www. ide.go.jp/Japanese/Publish/Download/Seisaku/201307_mide.html

Swisher, Clayton E. The Truth About Camp David: The Untold Story About the Collapse of the Middle East Peace Process. New York, Nation Books, 2004.

Takahara, T. "Japan." In Findlay, T., (ed.) Challenges for New Peacekeepers. Oxford: Oxford University Press, 1996.

Taylor, P. Warming Relations Between Israel and Japan Result in Trade Agreement, Jan 2015 US State Department, National Archives and Records Administration, RG 59, Central Files 1964-66, DEF 12-5 JORDAN. Secret; Immediate; Exdis. Received on March 10 at 8:38 p.m. and passed to the White House and DOD., outlining Johnson Administration plans to sell to Israel that balances sale to Jordan. This memo is reproduced and housed by the Jewish Virtual Library, https://www.jewishvirtuallibrary.org/u-s-promises-arms-sale-toisrael-that-balances-sale-to-jordan-march-1965

Togo, K. Japan's Foreign Policy, 1945-2009: The Quest for a Proactive Policy. Leiden: Brill Academic, 2010. 
Touval, S. Mediators in the Arab-Israeli Conflict, 1948-1979. New Jersey: Princeton University Press, 1982.

Waage, H.H. "“The 'Minnow' and the 'Whale" Norway and the United States in the Peace Process in the Middle East." British Journal of Middle Eastern Studies, vol. 34 , no. 2, 2007, pp 157-176.

Yamanaka, A. "Why Japan Needs to Contribute to International Peace Now." Gunshuku Mondai Shiryou [Journal for Disarmament Issues], March 2003.

Yoshizaki, T. "The Role of the Military in Peace-Building: A Japanese Perspective." Proceeding of NIDS International Symposium on Security Affairs 2008-2009, Tokyo: NIDS, 2008, http://www.nids.mod.go.jp/english/event/symposium/pdf/2008/e_12.pdf

Zhao, Minghao. "China's New role as a Middle East Peacemaker", The Japan Times, 4 February 2016, https://www.japantimes.co.jp/opinion/2016/02/04/ commentary/world-commentary/chinas-new-role-middle-east-peacemaker/

Open Access This chapter is licensed under the terms of the Creative Commons Attribution 4.0 International License (http://creativecommons.org/licenses/ by $/ 4.0 /$ ), which permits use, sharing, adaptation, distribution and reproduction in any medium or format, as long as you give appropriate credit to the original author(s) and the source, provide a link to the Creative Commons licence and indicate if changes were made.

The images or other third party material in this chapter are included in the chapter's Creative Commons licence, unless indicated otherwise in a credit line to the material. If material is not included in the chapter's Creative Commons licence and your intended use is not permitted by statutory regulation or exceeds the permitted use, you will need to obtain permission directly from the copyright holder.

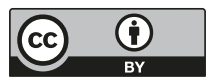

